\title{
Shea (Vitellaria paradoxa C.F. Gaertn.) Growth Improvement by Mycorrhizal Inoculation in Controlled Conditions
}

\author{
Haro Hadou ${ }^{1, ~ *, ~ G a n a b a ~ S o u l e y m a n e ~}{ }^{2}$, Sanon Bibata Kadidia ${ }^{1}$ \\ ${ }^{1}$ Microbiology Laboratory, Environment and Forests Department, Environment and Agricultural Research Institute, Ouagadougou, Burkina \\ Faso \\ ${ }^{2}$ Environment and Forests Department, Environment and Agricultural Research Institute, Ouagadougou, Burkina Faso
}

\author{
Email address: \\ harohadou@yahoo.fr (H. Haro) \\ ${ }^{*}$ Corresponding author
}

\section{To cite this article:}

Haro Hadou, Ganaba Souleymane, Sanon Bibata Kadidia. Shea (Vitellaria paradoxa C.F. Gaertn.) Growth Improvement by Mycorrhizal Inoculation in Controlled Conditions. Advances in Bioscience and Bioengineering. Vol. 8, No. 4, 2020, pp. 73-77.

doi: $10.11648 /$ j.abb.20200804.12

Received: October 10, 2020; Accepted: November 14, 2020; Published: November 16, 2020

\begin{abstract}
This study is Shea Park restoration contribution. In this study, Shea butter was cultivated for 12 months on non-sterile culture substrate and then inoculated with arbuscular mycorrhizal fungi (AMF). The mycorrhizal parameters were evaluated at 12 months after sowing and the growth parameters of the plants at 4 and 12 months after sowing. The results showed mycorrhizal infection of all treatments and stimulation of Shea's growth according to inocula. Yac 2 mix allowed a better improvement Shea growth. This inoculum improved Shea height growth by $10.34 \%$ at 4 months and $29.02 \%$ at 12 months after sowing compared to the treatment inoculated with Glomus aggregatum, by $46.02 \%$ at 4 months and $80.71 \%$ at 12 months after sowing compared to controls. Glomus aggregatum improved Shea height by $32.33 \%$ at 4 months and $40.06 \%$ at 12 months after sowing compared to controls. This inoculum also improved the Shea collar diameter by $12 \%$ at 4 months and $28.53 \%$ at 12 months after sowing compared to the treatment inoculated with Glomus aggregatum, by $53.86 \%$ at 4 months and $75.85 \%$ at 12 months after sowing compared to controls. Glomus aggregatum improves the Shea height by $37.38 \%$ at 4 months and $36.81 \%$ at 12 months after sowing compared to controls. Yac 2 mix also improves the height relative growth rate by $33.33 \%$ and the collar diameter relative growth rate by $54.54 \%$ compared to the controls. This study has shown promising results for the restoration of the Shea Park and deserves to be deepened by extending it to other mycorrhizal strains.
\end{abstract}

Keywords: Shea (Vitellaria paradoxa), Mycorrhizal Inoculation, Arbuscular Mycorrhizal Fungi

\section{Introduction}

Shea (Vitellaria paradoxa C.F. Gaertn.) is ecological and economic importance tree. It is an important source of nontimber forest products (mainly for butter extracted from almonds) [1, 2]. In Burkina Faso, it is the fourth-largest export product after gold, cotton and the live stock sector. This country is the second-largest producer of Shea butter in the world after Nigeria and is ranked third exporting countries behind Nigeria and Mali. With 195 million Shea trees in an area of $28 \%$ of the national territory, the production of Shea in Burkina Faso varies between 450,000 and 600,000 tons per year. The contribution of this sector to the domestic product is in order of USD 60 million \$, which represents between $0.5 \%$ and $1 \%$ of all activities. In Burkina Faso, there are several activities around the Shea sector. In this sector, the Shea production is one of the most important activities and mainly involves women. However, in this country, the Shea Park is very aging because its difficult regeneration, linked to its long juvenile phase (flowering begins at 10-25 years after sowing) and its slow growth which discourages Shea tree plantations. Only the process of natural regeneration currently ensures the renewal of its feet [3]. The Shea sector therefore faces the difficulties of maintaining and growing production due to the decrease in the frequency of trees in the field. This species density in the 
Sudanian zone increased from 230 trees/ha in 1940 [4] to 11 trees/ha in 2000 [5]. Thus, it becomes necessary and even urgent to interest in its regeneration, but the soils of Burkina Faso are generally poor in nutrients mainly nitrogen and phosphorus [6] and these trees growth depends on the climatic conditions. So, it appears essential to renew Shea Park by developing methods to shorten the juvenile phase while improving the Shea plant growth. However, the Shea roots establish symbiosis with arbuscular mycorrhizal fungi (AMF) [7]. Mycorrhizal symbiosis with AMF, a mutually beneficial association in which fungi enhance the growth of their hosts even when it grows on relatively nutrient poor soils [8]. However, inoculation lack responses in field experiments are frequently reported [9]. This is linked to inoculum-used competitiveness and efficiency. In addition, mycorrhizal inoculation can also cause host plant depression [9], hence the need to select the best fungi beneficial to Shea. This study was initiated with the aim to contribute to Shea's regeneration by improving these growths by AMF inoculation.

\section{Materials and Methods}

\subsection{Plant and Fungal Materials}

Shea nuts were used in this study. Fungal material was composed of two AMF inocula including an efficient local mixed inoculum isolated from the rhizosphere of cowpea cultivated in Burkina Faso [9] [Yac 2 mix (Scutellospora sp., Gigaspora sp., Glomus sp.)], and a fungal inoculum from the collection of the "Laboratoire Commun de Microbiologie (LCM)" of Senegal [Glomus aggregatum (Ga)]. The inoculum was produced in greenhouses [10]. Mycorrhizal inoculum production consisted of multiplying AMF. Thus, maize (Zea mays) is grown in greenhouses in 7 liter pots containing $7 \mathrm{~kg}$ of sterile soil and inoculated with AMF. The control pots also received $7 \mathrm{~kg}$ of sterile soil each, but were not inoculated. Each treatment is repeated 3 times and the test lasted 6 months. The inoculum is composed of a mixture of spores, mycorrhized roots fragments and soil. This inoculum is stored at $4{ }^{\circ} \mathrm{C}$.

\subsection{Culture Substrate}

The culture substrate was a non-sterile soil whose physicochemical characteristics are: clay: $3.92 \%$; total silt: 5.88\%; total sand: $90.2 \%$; total organic matter: $0.331 \%$; total carbon: $0.192 \%$; total nitrogen: $0.016 \% ; \mathrm{C} / \mathrm{N}: 12$; total phosphorus: $172.52 \mathrm{ppm}$; available phosphorus: $1.74 \mathrm{ppm}$; $\mathrm{pH} \mathrm{H}_{2} \mathrm{O}(\mathrm{w} / \mathrm{v}: 1 / 2.5), 6.44$.

\subsection{Test Implementation}

The test consisted of Shea growing in 7 liter pots containing $7 \mathrm{~kg}$ of culture substrate. The Shea nuts were sown at the rate of 1 per pot and the inoculation was carried out at sowing time with $10 \mathrm{~g}$ of inocula (as described by Haro et al. [8]) per pot for each inoculated treatment. Control pots were not inoculated. This device was composed of 3 treatments [two inoculated treatments (Yac $2 \mathrm{mix}$ and $\mathrm{Ga}$ ) and one control] with 40 replicates per treatment has been retained. The experimental design used was a simple randomization complete block design. This experiment lasted 12 months.

To estimate the Shea growth response of mycorrhizal inoculation, grow parameters were measured.

\subsection{Grow Parameters Measurement}

To estimate the Shea growth effect of mycorrhizal inoculation, the height, the collar diameter, height relative growth rate and collar diameter relative growth rate were calculated at the $4^{\text {th }}$ and at the $12^{\text {th }}$ month after sowing. The height relative growth rate (RGRh) was calculated according to the formula (1) [11-13]:

$$
R G R h=\frac{\ln \left(H_{2}\right)-\ln \left(H_{1}\right)}{T_{2}-T_{1}}
$$

with $\mathrm{H}$ : height, $\mathrm{T}$ : time, ${ }_{1}$ : initial, ${ }_{2}$ : final.

The collar diameter was measured using a caliper at the separation zone between the root system and the aerial part of 4 and 12 months after sowing. The collar diameter relative growth rate (RGRDc) was calculated according to the formula (2) [11-13]:

$$
R G R D C=\frac{\ln \left(D c_{2}\right)-\ln \left(D c_{1}\right)}{T_{2}-T_{1}}
$$

with Dc: collar diameter, T: time, ${ }_{1}$ : initial, ${ }_{2}$ : final

\subsection{Staining for Mycorrhizal Colonization}

The fine roots from each treatment was thoroughly washed and placed in falcon tubes then cleared using $10 \% \mathrm{KOH}$. They were heated in $90^{\circ} \mathrm{C}$ water bath for one hour. The roots were washed with tap water for 30 minutes' bath in $7.5 \%$ hydrogen peroxide is added to the procedure in order to achieve better root discoloration [14]. The roots were again washed with tap water. Staining was then done by adding $0.05 \%$ trypan blue in lactic acid and heating in $90^{\circ} \mathrm{C}$ water bath for 30 minutes as described by Phillips, Hayman [15] and observation was made under the microscope (magnification $=10 \mathrm{x}$ ). The mycorrhizal frequency and intensity were estimated by Trouvelot et al. [16] method.

\subsection{Statistical Analysis}

Data were statistically analysis with the statistical software XLSTAT 2019. When the variable from which the sample is drawn follows a normal distribution and the samples variances are homogeneous, the data (height relative growth rate) are analyzed using a one-way analysis of variance (ANOVA) and the variables means were compared using the Newman Keuls test $(\mathrm{p}<5 \%)$.

All other data (height, collar diameter, collar diameter relative growth, mycorrhization frequency and intensity) were analyzed using a Kruskal-Wallis test and row means were compared using the Conover-Iman test $(p<5 \%)$. 


\section{Results and Discussion}

\subsection{Mycorrhization Evaluation}

Shea mycorrhizal infection results (table 1) shows that mycorrhization was variable from mycorrhizal strains. The Shea mycorrhization frequency and intensity are generally low. The control treatment shows mycorrhizal infection traces. These traces of mycorrhizal infection on the controls roots show that the substrate used contains AMF. This could be explained by the fact that the culture substrate was not sterilized. Similar results were obtained by Haro et al. [10] who found cowpea roots was mycorrhizal on the non-sterile substrate. The highest values are obtained with the Yac 2 mix inoculum both the frequency $(37.75 \%)$ and the intensity of mycorrhization (15.61\%). Statistical analyzes show significant differences $(\mathrm{p}<0.05)$ between the different treatments. Mycorrhizal infection is higher on the inoculated treatments compared to the control. These results are justified by the fact that the mycorrhizal strains used would be more competitive than those of the substrate. However, inoculation is only beneficial if the strains used are more competitive than the existing strains in the soil [17]. The low mycorrhizal infection of the control treatment would so be linked to the number of fungal propagules initially present in the substrate compared to inocula. Therefore, the stimulation of growth between the inoculated treatments compared to the control could be attributed to the effect of the inoculated arbuscular mycorrhizal fungi since the effects of the symbiosis with the $\mathrm{AMF}$ and the plants depend on the intra and interspecific competitiveness of the communities [18], the functional and physiological compatibility between the symbionts and the interactions between plants, soil and fungi [19]. Similar results were found by Zaouchi et al. [20] on Jacaranda mimosifolia. The fungal propagules number determination would have made it possible to better discuss these results.

Table 1. Vitellaria paradoxa mycorrhizal frequency and intensity 60 days after sowing inoculated with 2 mycorrhizal inocula [Yac 2 mix and Glomus $\operatorname{aggregatum}(G a)]$.

\begin{tabular}{lll}
\hline Treatments & $\begin{array}{l}\text { Mycorrhizal } \\
\text { frequency (\%) }\end{array}$ & $\begin{array}{l}\text { Mycorrhizal } \\
\text { intensity (\%) }\end{array}$ \\
\hline Yac 2 mix & $35.25 \pm 1.19^{\mathrm{a}}$ & $15.61 \pm 0.63^{\mathrm{a}}$ \\
$\mathrm{Ga}$ & $37.75 \pm 0.91^{\mathrm{b}}$ & $5.55 \pm 0.31^{\mathrm{b}}$ \\
Control & $2.75 \pm 0.02^{\mathrm{c}}$ & $0.05 \pm 0.02^{\mathrm{c}}$ \\
Significance level & $<0.0001$ & $<0.0001$ \\
\hline
\end{tabular}

For the same column, data followed by the same letters are not significantly different according to the Conover-Iman test $(\mathrm{p}<0.05)$.

Standard error of the mean $(n=40)$.

\subsection{Grow Parameters Evaluation}

Table 2 presents the Shea grows parameters measurement results. The results of Shea's height are variable and depend on the inoculum. Statistical analyzes show significant differences $(\mathrm{P}<0.0001)$ between the different treatments for 4 months and 12 months after sowing. Heights are generally higher for inoculated plants compared to uninoculated ones. The highest values are obtained with the Yac 2 mix inoculum at 4 months $(15.58 \mathrm{~cm})$ and at 12 months $(30.72$ $\mathrm{cm})$ after sowing. This inoculum improves the Shea height growth by $10.34 \%$ at 4 months and $29.02 \%$ to 12 months after sowing compared to the treatment inoculated with Glomus aggregatum, by $46.02 \%$ at 4 months and $80.71 \%$ to 12 months after sowing compared to controls. The Glomus aggregatum inoculum improves the Shea height growth by $32.33 \%$ at 4 months and $40.06 \%$ to 12 months after sowing compared to controls. The collar diameter results are similar to those obtained from the height. The highest values are obtained with Yac 2 mix inoculum at 4 months $(13.17 \mathrm{~mm})$ and at 12 months $(19.73 \mathrm{~mm})$ after sowing. This inoculum improves the Shea collar diameter grow by $12 \%$ at 4 months and $28.53 \%$ to 12 months after sowing compared to the treatment inoculated with Glomus aggregatum, by $53.86 \%$ at 4 months and $75.85 \%$ to 12 months after sowing compared to controls. The Glomus aggregatum inoculum improves the Shea collar diameter grow by $37.38 \%$ at 4 months and $36.81 \%$ to 12 months after sowing compared to controls.

These improvements could be explained by the increased Shea mineral nutrition. Similar results were obtained by Haro, Sanon [21]. Indeed, these authors have shown that mycorrhizal inoculation improves Sesamum indicum growth and biomass production. These results corroborate those of Song et al. [22] who found that inoculum had a direct impact on maize growth. These results are in agreement with those of Elliott et al. [23] who showed that mycorrhizal inoculation increased phosphorus uptake in wheat by up to $30 \%$.

The improvement in growth depends on the inoculum and in this study; the inoculum Yac 2 mix allows a better improvement of Shea's growth. These results are justified by the fact that the effectiveness of this symbiosis depends on the compatibility between the plant material used and the fungal strain present. These results are in agreement with those of Mensah et al. [24] who showed that the response of plants to mycorrhizal inoculation with AMF ranges from very beneficial to harmful.

The improvement in Shea's growth by mycorrhizal inocula is more noticeable at 12 months than at 4 months after sowing, suggesting that the effect of these AMF increases over time. This could be justified by the fact that the effect of arbuscular mycorrhizal fungi on host plants depends on the mineral composition of the soil. Thus, more the soil is rich in mineral elements, less the beneficial effect of AMF will be perceptible on the host plants. However, the culture substrate contained mineral elements directly accessible to the roots of the test start. These nutrients were depleted over time as the plants grew. Similar results were obtained by Haro et al. [25]. These authors showed that mycorrhizal inoculation that was ineffective at the test start (the first 30 days after sowing) was very beneficial for Mucuna pruriens by improving its growth and production of shoot, root and total biomass at 60 days after sowing.

Statistical analyzes at the height relative growth rate show significant differences $(\mathrm{P}<0.001)$ between the treatment inoculated with Yac $2 \mathrm{mix}$ and the other treatments. 
However, these statistical analyzes shows no significant difference between the treatments inoculated with Glomus aggregatum and the control. The same is true for the collar diameter relative growth rate. The highest values are obtained for inoculation with Yac $2 \operatorname{mix}(0.0028$ $\mathrm{cm} /$ month.cm for RGRh and $0.0017 \mathrm{~mm} / \mathrm{month} . \mathrm{mm}$ for RGRDc). Similar results were found by Haro et al. [26] on maize.

Table 2. Plant height, the collar diameter, the height of relative growth rate and the collar diameter of relative growth rate of Vitellaria paradoxa inoculated with 2 mycorrhizal inocula [Yac 2 mix and Glomus aggregatum (Ga)].

\begin{tabular}{|c|c|c|c|c|c|c|}
\hline Treatments & Height 1 (cm) & Height $2(\mathrm{~cm})$ & $\begin{array}{l}\text { RGRh } \\
\text { (cm/month.cm) }\end{array}$ & $\begin{array}{l}\text { Collar diameter } 1 \\
(\mathrm{~mm})\end{array}$ & $\begin{array}{l}\text { Collar diameter } 2 \\
(\mathrm{~mm})\end{array}$ & $\begin{array}{l}\text { RGRdc } \\
\text { (mm/month.cm) }\end{array}$ \\
\hline Yac 2 mix & $15.58 \pm 0.31 \mathrm{a}$ & $30.72 \pm 0.59 \mathrm{a}$ & $0.0028 \pm 0.0001 \mathrm{a}$ & $13.17 \pm 0,13 \mathrm{a}$ & $19.73 \pm 0.26 \mathrm{a}$ & $0.0017 \pm 0.0001 \mathrm{a}$ \\
\hline $\mathrm{Ga}$ & $14.12 \pm 0.43 b$ & $23.81 \pm 0.35 b$ & $0.0022 \pm 0.0001 b$ & $11.76 \pm 0.26 \mathrm{~b}$ & $15.35 \pm 0.22 \mathrm{a}$ & $0.0012 \pm 0.0001 \mathrm{~b}$ \\
\hline Control & $10.67 \pm 0.44 c$ & $17 \pm 0.7 \mathrm{c}$ & $0.0021 \pm 0.0001 b$ & $8.56 \pm 0.29 c$ & $11.22 \pm 0.22 \mathrm{c}$ & $0.0011 \pm 0.0001 b$ \\
\hline Significance level & $<0.0001$ & $<0.0001$ & 0.001 & $<0.0001$ & $<0.0001$ & $<0.0001$ \\
\hline
\end{tabular}

For the same column (height, collar diameter and RGRdc), data followed by the same letters are not significantly different according to the Conover-Iman test $(\mathrm{p}<0.05)$.

For the RGRh column, data followed by the same letters are not significantly different according to the Newman-Keuls test ( $\mathrm{p}<0.05$ ).

Standard error of the mean $(n=40)$.

\section{Conclusion and Recommendation}

This study, which aimed to improve the Shea growth, showed that this plant responds positively to mycorrhizal inoculation. From these results, it is now established that mycorrhizal inoculation with arbuscular mycorrhizal fungi enhances the Shea growth. It would therefore be possible to improve the Shea adaptation of soils lacking in mineral elements. From this study, it appeared that the effect of inoculation varied depending on the inoculum. This suggests that the beneficial effect of mycorrhizae on Shea's growth may be optimized by selection from combinations of multiple mycorrhizal strains. Hence the need to deepen this study by increasing the number of inocula.

\section{Acknowledgements}

This study received funding from the Denmark Kingdom Embassy through the LGA/Karité DK Project (104BKF 43-116).

\section{References}

[1] Hall JB, Aebischer DP, Tomlinson HF, Osei-Amaning E, Hindle JR (1996) Vitellaria paradoxa: a monograph. School of Agricultural and Forest Sciences, University of Wales, Bangor.

[2] Lovett PN, Haq N (2000) Evidence for anthropic selection of the Sheanut tree (Vitellaria paradoxa). Agroforestry Systems 48 (3): 273-288. doi: 10.1023/a:1006379217851.

[3] Augusseau X, Nikiéma P, Torquebiau E (2006) Tree Biodiversity, Land Dynamics and Farmers' Strategies on the Agricultural Frontier of Southwestern Burkina Faso. Biodiversity and Conservation 15 (2): 613-630. doi: 10.1007/s10531-005-2090-8.

[4] Chevalier A (1946) L'arbre à beurre d'Afrique et l'avenir de sa culture. Oléagineux 1 (1): 7-11.

[5] Nikiema A, Van Der Maesen LJG, Hall JB (2003) The impact of parkland management practices on plant resources diversity. Improved management of agroforestry parkland systems in Sub-Saharan Africa. EU/INCO Project Contract
IC18-CT98-0261, Final report, University of Wales Bangor, UK: $43-50$.

[6] Bado BV (2002) Rôle des légumineuses sur la fertilité des sols ferrugineux tropicaux des zones guinéenne et soudanienne du Burkina Faso. Philosophiae Doctor (Ph. D.), Université de Laval.

[7] Dianda M, Ouedraogo SJ, Diop TA (2010) Variation de la réponse à l'endomycorhization en pépinière des plants issus de deux semenciers de karité a.u Burkina Faso. Int J Biol Chem Sci 4 (5): 1742-1752.

[8] Haro H, Sanon KB, Le Roux C, Duponnois R, Traoré AS (2017) Improvement of cowpea productivity by rhizobial and mycorrhizal inoculation in Burkina Faso. Symbiosis: 1-14. doi: 10.1007/s13199-017-0478-3.

[9] Haro H (2016) Optimisation des symbioses rhizobienne et mycorhizienne pour améliorer la productivité du niébé [Vigna unguiculata (L.) Walp.] au Burkina Faso. (Ph. D.), Université Ouaga 1 Professeur Joseph Ki-Zerbo.

[10] Haro H, Sanon KB, Diop I, Kane A, Dianda M, Houngnandan P, Neyra M, Traoré A (2012) Réponse à l'inoculation mycorhizienne de quatre variétés de niébé [Vigna unguiculata (L.) Walp.] cultivées au Burkina Faso et au Sénégal. International Journal of Biological and Chemical Science 6 (5): 2097-2112. doi: http://dx.doi.org/10.4314/ijbcs.v6i5.18.

[11] Hoffmann WA, Poorter H (2002) Avoiding bias in calculations of relative growth rate. Annals of botany 90 (1): 37-42. doi: $10.1093 / \mathrm{aob} / \mathrm{mcf} 140$.

[12] Beadle CL (1985) Plant Growth Analysis. In: Coombs J, Hall DO, Long SP, Scurlock JMO (eds) Techniques in Bioproductivity and Photosynthesis. Pergamon, pp 20-25. doi: 10.1016/b978-0-08-031999-5.50012-1.

[13] Blackman VH (1919) The Compound Interest Law and Plant Growth. Annals of botany 33 (131): 353-360.

[14] Kormanik PP, McGraw AC (1982) Quantification of vesicular-arbuscular mycorrhizae in plant roots. Methods and Principles of Mycorrhizal Research (Schenck NC, ed) Univ Florida Ann Phytopathol Soc St Paul, Minnesota: 37-45.

[15] Phillips JM, Hayman DS (1970) Improved procedures for clearing roots and staining parasitic and vesicular-arbuscular mycorrhizal fungi for rapid assessment of infection. Transactions of the British Mycological Society 55 (1): 158161. 
[16] Trouvelot A, Kough JL, Gianinazzi-Pearson V, Gianinazzi S (1986) Mesure du taux de mycorhization VA d'un système radiculaire. Recherche de méthodes d'estimation ayant une signification fonctionnelle. Mycorrhizae: physiology and genetics: $217-221$.

[17] Bâ AM, Dalpé Y, Guissou T (1996) Les glomales d'Acacia holosericea et d'Acacia mangium. Bois et forêts des tropiques 250: 5-18

[18] Watkinson AR, Freckleton RP (1997) Quantifying the impact of arbuscular mycorrhiza on plant competition. Journal of Ecology 85 (4): 541-545.

[19] Miller RM, Kling M (2000) The importance of integration and scale in the arbuscular mycorrhizal symbiosis. Plant and Soil 226 (2): 295-309. doi: 10.1023/A:1026554608366.

[20] Zaouchi Y, Bahri NB, Rezgui S, Bettaieb T (2013) Effects of arbuscular mycorrhizal inoculation and fertilization on mycorrhizal Statute of Jacaranda mimosifolia D. Don cultivated in nurseries. Comptes rendus biologies 336 (10): 493-499. doi: 10.1016/j.crvi.2013.09.005.

[21] Haro H, Sanon KB (2020) Réponse du sésame (Sesamum indicum L.) à l'inoculation mycorhizienne avec des souches des champignons mycorhiziens arbusculaires indigènes du Burkina Faso. International Journal of Biological and Chemical Science $14 \quad$ (2): 417-423. doi: https://dx.doi.org/10.4314/ijbcs.v14i2.9.
[22] Song Z, Bi Y, Zhang J, Gong Y, Yang H (2020) Arbuscular mycorrhizal fungi promote the growth of plants in the mining associated clay. Scientific reports 10 (1): 2663. doi: 10.1038/s41598-020-59447-9.

[23] Elliott AJ, Daniell TJ, Cameron DD, Field KJ (2020) A commercial arbuscular mycorrhizal inoculum increases root colonization across wheat cultivars but does not increase assimilation of mycorrhiza-acquired nutrients. Plants, People, Planet n/a (n/a). doi: 10.1002/ppp3.10094.

[24] Mensah JA, Koch AM, Antunes PM, Kiers ET, Hart M, Bucking H (2015) High functional diversity within species of arbuscular mycorrhizal fungi is associated with differences in phosphate and nitrogen uptake and fungal phosphate metabolism. Mycorrhiza: 1-14. doi: 10.1007/s00572-0150631-x.

[25] Haro H, Semdé K, Bahadio K, Sanon BK (2020) Effet de l'inoculation mycorhizienne avec des souches des champignons mycorhiziens arbusculaires sur la croissance de Mucuna pruriens (L.) DC en condition contrôlée. International Journal of Biological and Chemical Science 14 (3): 10651073. doi: https://doi.org/10.4314/ijbcs.v14i3.32.

[26] Haro H, Semdé K, Bahadio K (2020) Native Arbuscular Mycorrhizal inoculation of Corn (Zea mays L.) cultivated in Burkina Faso. Journal of Applied Biosciences 149: 1529115296. doi: https://doi.org/10.35759/JABs.v149.3. 